\title{
CONCEPTUAL GROUNDS FOR ADMINISTERING EDUCATION PROCESS IN MODERN WORLD
}

\author{
Maryna Azhazha \\ Engineering Educational-Scientific Institute of Zaporizhzhia National University \\ Zhukovskoho Str. 60, Zaporizhzhia, 69600, Ukraine \\ azazmarina17@gmail.com, https://orcid.org/0000-0001-6067-3926 \\ Oksana Zhukova \\ V. N. Karazin Kharkiv National University \\ Svobody Sq., 4, Kharkiv, Ukraine, 61022 \\ edu.pedagogika@gmail.com, https://orcid.org/0000-0001-9724-9598
}

Jana Peliova

University of Economics in Bratislava

Dolnozemska cesta 1, 85235 Bratislava, Slovakia jana.peliova@euba.sk,https://orcid.org/0000-0002-0305-0906

Veronika Shkrabiuk

Vasyl Stefanyk Precarpathian National University Shevchenko St. 57, Ivano-Frankivsk, 76018, Ukraine, veronika.shkrabiuk@pnu.edu.ua, https://orcid.org/0000-0002-7602-0732

\begin{abstract}
The article based on the analysis of the literature, identifies the general patterns of development of lifelong learning. The need for lifelong learning is considered; basic competencies that help in this, as well as the relevance of the choice and use of these competencies in modern society. It is investigated that in the conditions of European integration of Ukraine and innovative management under the influence of social and economic transformations requirements to the quality of professional training of future experts grow. Balanced management of the modernization of higher education and the market of educational services it provides will provide a strong, high level of personal and professional competence with strong, innovative knowledge, personal and professional competence, strong human potential. The key problems of post-industrial production, the technologies of which are constantly updated, have been identified, and many specialists are forced to retrain, change qualifications or the profession in general. Therefore, lifelong learning becomes relevant, which is the basis for the self-realization of each individual, a factor in the formation of powerful human capital, a determinant of the economic prosperity of Ukraine. The fundamental principles of lifelong learning are studied. The study analyses the methodological aspects of lifelong learning, which reveal the spatial approach (which allows you to analyse the interdependent continuous, subordinate socio-political and cultural processes); multilevel approach (which analyses the relationships and interactions of the reproduction of human capital at the micro-, meso, and macro levels, taking into account global, global, regional and local factors influencing the political, economic, socio-cultural trends of intellectual society). The expediency of applying the experience of the European Union countries and, in particular, Slovakia in Ukraine to increase the efficiency of lifelong education administration is substantiated.
\end{abstract}

Key words: continuing education, adult education, lifelong learning, administration, management. 
2021 Випуск/ Issue 48

\title{
М. А. Ажажа
}

Інженерний навчально-науковий інститут Запорізького національного університету вул. Жуковського, 60, м. Запоріжжя, 69600, Україна

\section{О. А. Жукова}

Харківський національний університет імені В. Н. Каразіна

площа Свободи 4, Харків, 61022, Україна

\section{Я. Пеліова}

Економічний університет в Братиславі

Дольноземське шосе, 1, м. Братислава, 85235, Словаччина

\section{В. С. Шкраб'юк}

Прикарпатський національний університет імені Василя

Стефаника, вул. Шевченка, 57, м. Івано-Франківськ, 76018, Україна

\section{КОНЦЕПТУАЛЬНІ АСПЕКТИ АДМІНІСТРУВАННЯ ОСВІТИ В УМОВАХ СУЧАСНОГО СВІТУ}

\begin{abstract}
У статті на основі аналізу літератури визначено загальні закономірності розвитку освіти впродовж життя, яка є підґрунтям для самореалізації кожної особистості, чинником формування потужного людського капіталу, детермінантою економічного процвітання України. Зроблено акцент на базових компетентностях, на підґрунті яких слід вибудовувати діяльність, а також на актуальності використання цих компетентностей у сучасному соціумі. Зазначено, що в умовах європейської інтеграції України під впливом соціально-економічних перетворень зростають вимоги до якості професійної підготовки майбутніх фахівців-управлінців. Доведено, що збалансований менеджмент вищої освіти та ринку освітніх послуг, які він надає, забезпечить міцний, високий рівень особистісного та професійного зростання майбутніх управлінців. Виявлено ключові проблеми постіндустріального виробництва, технології якого постійно оновлюються. Вказано на принципи освіти впродовж життя та шляхи вирішення актуальних проблем: перенавчання, зміна кваліфікації або професії загалом. В дослідженні проаналізовано методологічні аспекти розвитку освіти впродовж життя, які розкривають наступні підходи: просторовий (дозволяє аналізувати взаємозумовлені неперервні, субординаційні соціально-політично-культурні процеси); багаторівневий (аналізує взаємозв'язки та взаємовплив відтворення людського капіталу на мікро-, мезо-, макрорівнях, з урахуванням глобальних, світових, регіональних і локальних факторів впливу на політичні, економічні, соціально-культурні тенденції розвитку інтелектуального суспільства). Обґрунтовано доцільність застосовування в Україні досвіду країн Європейського Союзу і, зокрема, Словаччини задля підвищення ефективності адміністрування освіти.
\end{abstract}

Ключові слова: неперервна освіта, освіта дорослих, освіта впродовж життя, адміністрування, менеджмент.

\section{М. А. Ажажа}

Инженерный учебно-научный институт Запорожского национального университета

ул. Жуковского, 60, м. Запорожье, 69600, Украина

\section{О. А. Жукова}

Харьковский национальный университет имени В.Н. Каразина

пл. Свободы 4, Харьков, 61022, Украина,

\section{Я. Пелиова}

Экономический университет в Братиславе

Дольноземское шоссе, 1, г. Братислава, 85235, Словакия

\section{В. С. Шкрабьюк}

Прикарпатский национальный университет имени Василия

Стефаника, ул. Шевченко, 57, г. Ивано-Франковск, 76018, Украина

\section{КОНЦЕПТУАЛЬНЫЕ АСПЕКТЫ АДМИНИСТРИРОВАНИЯ ОБРАЗОВАНИЯ В УСЛОВИЯХ СОВРЕМЕННОГО МИРА}

В статье на основе анализа литературы определены общие закономерности развития образования на протяжении жизни, которые являются основой для самореализации каждой личности, фактором формирования мощного человеческого капитала, детерминантой экономического процветания Украины. Сделан акцент на базовых компетентностях, на основе которых следует выстраивать деятельность, а также на актуальности их использования в современном социуме. Отмечено, что в условиях европейской интеграции Украины под влиянием социально-экономических преобразований растут требования к качеству профессиональной подготовки будущих специалистов-управленцев. Доказано, что сбалансированный менеджмент высшего образования и рынка образовательных услуг, которые он предоставляет, обеспечит крепкий, высокий уровень личностного и профессионального роста будущего управленца. Выявлены ключевые проблемы постиндустриаль- 
ного производства, технологии которого постоянно обновляются. Указано на принципы образования в течение жизни и пути решения актуальных проблем: переобучение, изменение квалификации или и профессии в целом. В исследовании проанализированы методологические аспекты развития образования на протяжении жизни, которые раскрывают следующие подходы: пространственный (позволяет анализировать взаимообусловлены непрерывные, субординационные социально-политически-культурные процессы); многоуровневый (анализирует взаимосвязи и взаимовлияние воспроизводства человеческого капитала на микро-, мезо-, макроуровнях, с учетом глобальных, мировых, региональных и локальных факторов влияния на политические, экономические, социально-культурные тенденции развития интеллектуального общества). Обоснована целесообразность применения в Украине опыта стран Европейского Союза и, в частности Словакии, для повышения эффективности администрирования образования.

Ключевые слова: непрерывное образование, образование взрослых, образование в течение жизни, администрирование, менеджмент.

Introduction. A factor of continuous, prolonged in time and the dimension of personal growth and development of modern man is the current trend of the new millennium - lifelong learning, which has its vector of development and has a proactive impact on economic, political, legal, social and cultural spheres. Lifelong learning also affects the security, science, ideology, and spiritual health of the nation and the constant renewal of public life in the process of gradual enrichment of previously acquired knowledge and skills. After all, the progressive progress of the state directly depends on the level of education of its citizens, able to be successful and competitive in personal and professional terms. In the conditions of post-industrial production, the technologies of which are constantly updated, many specialists are forced to retrain, change qualifications or profession in general. Numerous studies show that the automation processes that have accelerated in the 21st century will lead to job cuts in traditional sectors. For example, in the United States, most workers in the transportation and logistics professions, the majority of employees and administrative workers, as well as the workforce in the manufacturing professions are at risk of losing their jobs [14]. Therefore, the creation of conditions for lifelong learning and its administration is a necessary prerequisite for the sustainable development of society.

Review of related literature and hypotheses. We find topical issues concerning the problems of education in the works of famous Ukrainian and Slovak researchers $[8 ; 13 ; 18]$.

The implementation issue of the Bologna process in Ukraine and Slovakia is reflected in the works M. Azhazha [1], O. Dubaseniuk [3], M. Stepko [11] and others.

Various aspects of state policy in the context of education modernization have been studied by Ukrainian and foreign scholars and practition- ers. The essence of education has been studied throughout life O. Pashchenko, L. Yakovenko [12].

L. Yakovenko points to the existence of four main subjects of modernization of higher education: 1) consumers who receive educational services (individual or team); 2) providers (manufacturers) that provide educational services (public or private educational institutions); 3 ) the state, which to some extent regulates the market of educational services and orders the training of specialists within the state funding; 4) society, because it feels the impact of raising or lowering the level of education on the social climate [12].

Within the state educational policy framework, the implementation of basic provisions of the lifelong learning concept in the context of knowledge society involves consolidating in the minds of Ukrainians of understanding of mutual responsibility of society, state, and individual for educational processes.

The basis for the formation of lifelong learning was laid by Vocational Training Recommendation No. 117, adopted on June 27, 1962. In the Recommendations as to the main purpose of training it was determined that it is not an end in itself, but a means of developing the professional abilities of those who undergo it. Training should be aimed at personal development. Learning is a single whole, which is characterized by the interdependence of its various elements, it is a process that lasts throughout the working life of human [10].

The "National Doctrine of Education Development" [7] states that education should become a strategic resource for ensuring national interests, improving people's living standards, increasing the competitiveness of the state, its authority on a global scale.

However, despite the considerable amount of scientific research related to the topic of the article, there is still no in-depth study of the problem of lifelong learning in Ukraine using a clear science-based management model. 
Results and discussion. Lifelong learning is the basis for the self-realization of each individual, a factor in the formation of powerful human capital, a determinant of the economic prosperity of Ukraine. Because of the above, the topic of the article is relevant, which is explained by the lack of a clear management model of scientific implementation of lifelong learning in Ukraine.

Awareness of lifelong learning importance for human development has led to the modernization of European education policy last 20 years. Thus, in March 2000, the Lisbon Summit of the Council of Europe adopted "Memorandum of Lifelong Learning" [16]. Therefore, in EU-countries there is a constant increase in investment in education, special grants, updating the range of educational services and technologies to create conditions for lifelong learning [17].

Nowadays, as V. Kremen noted, "society and individuals can be successful and effective only by being in constant change and, consequently, in dynamic development" [5]. The latest factors of public life, first of all, globalization and continuous informatization, democratization and formation of market relations, intensification of social relations and interstate cultural ties, motivate the education system to prepare people for life in new historical conditions. The prognostic advanced nature of education puts before the state the difficult task of developing managerial, organizational, scientific, and methodological foundations of an updated system of professional training of future professionals capable of responding to permanent changes in social development.

As O. Dubaseniuk rightly argues, the education system is undergoing radical changes in the context of the challenges of the 21st century due to the systemic crisis of human civilization. Accordingly, the modern paradigm of education development in Ukraine should be proactive and promote the introduction of innovative trends in education [3].

Back in 1996 the State National Program "Education" ("Ukraine of the XXI Century") emphasized the importance of solving the problem of renewing education, creating conditions for creative self-expression and personal development and creative self-realization of every citizen of Ukraine, because the dynamism inherent in modern civilization, growing social role, humanization and democratization of society, intellectualization of labour, rapid change of equipment and technology around the world - all this requires the creation of such conditions under which the people of Ukraine would become a nation that is constantly learning [2].
In September 2017, a new version of the Law of Ukraine "On Education" was adopted. Art. 18 defined "adult education", which is a component of lifelong learning and aims to realize the right for every adult to lifelong learning, taking into account her/his personal needs, social development priorities, and the needs of the economy. There are such components of adult education: postgraduate education; professional training of employees; retraining or training courses; professional development during their life, etc. [9].

The role of education in society is not only to "transmit knowledge and social results in general from generation to generation, but also to prepare people to overcome all sorts of global crises and catastrophes, which can be overcome using outdated knowledge, but only those that are ahead of time and lead to non-traditional actions" [11]. After all, it is not innovations in education that cause social change, but on the contrary, only social changes open the way to something new in education.

In a market economy, information, and technological development, the functions of vocational education are expanding, its transformation into vocational education and training is taking place, which corresponds to the world trends of continuing education - lifelong learning. In all civilized countries, there is an active search for new models of educational development, non-traditional approaches to their implementation based on information and communication technologies [8].

At present, "it is necessary: to form a holistic system of institutionally developed and legally authorized public bodies in higher education; to give public bodies the right to take a real part in resolving issues of the main activity of the higher school - up to the right to veto certain administrative decisions; determine the list of issues of higher education (education, granting the special status of the institution, etc.), on which administrative decisions cannot be made without the consent of the relevant public bodies; to legally establish the procedure for the formation and possible sources of financial and economic support for the activities of public bodies in higher education" [13].

Lifelong learning involves continuous investment into people and their knowledge; acquisition of basic skills, including digital literacy; dissemination of innovative, more flexible forms of learning. The goal is to provide all people (regardless of their age) with equal opportunities for access to education - relevant and high quality. The Council of Europe views lifelong learning as a key component of the social model of mod- 
ern Europe. It is worth noting that such training involves not only education. Education is an indispensable factor in ensuring employment, economic growth, and competitiveness of modern human [4].

Among the modern society trends, which contributed to the spread of the "lifelong learning" concept in developed countries, for Ukraine are particularly important acceleration of the renewal of professional knowledge - annually updated theoretical (about 5\%) and professional knowledge (about 20\%). The United States has adopted a unit of measurement of special knowledge - the "half-life" of competence. It means a period in which a person's competence is reduced by $50 \%$ due to new information. And for many professions, this period is constantly shortening and becoming less than 5 years. In the context of the Ukrainian higher education system, this means that, on the one hand, it is necessary to strengthen the practical component of the educational process [19], and on the other hand, to move to lifelong learning, when basic education should be supplemented from time to time. Therefore, the educational process should be organized not as final and complete, but only as a basis for further learning [6].

In the "Memorandum on Lifelong Learning", lifelong learning is defined as the main program of development of civil society, providing the social cohesion and employment [16].

The basic principles of lifelong learning outlined in this document are:

1) new basic skills and knowledge (such as entrepreneurship, foreign languages, technological culture, computer literacy, and soft skills) for all persons; the goal is to provide continuous access to education for obtaining and renewing the skills, which are necessary for the inclusion of human into the modern society;

2) increasing investment into human capital on the basis of social partnership and application of socially responsible business experience - to increase the priority of people;

3 ) innovative methods of teaching and learning (user orientation, personal motivation, critical thinking, learning ability, etc.); goal is to develop new teaching methodologies for the system of lifelong learning;

4) renewing system of education assessment (development of a quality system "Accreditation of Prior and Non-formal Education" (APEL); the goal is to increase the motivation for continuing education to radically change the approaches to understanding and recognition of educational activities, its results, especially in the field of non-formal and informal education);

5) mentoring and counselling development (creation of permanent counselling service to provide recommendations in the field of educational, professional, and personal development of the user); the goal is considered as providing everyone with suitable and free access throughout their lives to information about educational possibilities and the necessary consultations and recommendations;

6) bringing education closer to the place of residence; The aim is to provide people with better conditions for education through the location of a network of training and counselling centres as close as possible to the place of residence, as well as through the use of information technology [16]. All these principles are united by an understanding of the mutual responsibility of society, the state, and the individual for the development of educational processes.

The experience of the development of the educational system of Ukraine after 1991 shows that now at the system level in education models of changes prevail, which either only imitates them, or the transformation of existing institutions, organizational and educational practices involves action: it does not provide forecasting and modelling. is a spontaneous reaction to the appearance of this problem.

There are three main features in the content of continuing education: "related to adult learning (literacy training in a broad sense, including computer, language, social, etc.); vocational training, which includes vocational training, retraining, advanced training (job qualification); general cultural additional education, not related to employment (life qualification). Thereby, according to the goals set out in lifelong learning system, it can be divided into the such parts: 1) additional professional education, which contributes to the formation of the professional foundations of a competitive specialist for the modern economy at all levels; 2) education aimed at promoting the adaptation and rehabilitation of those groups who are unable to quickly adapt to the changing environment, as well as the adaptation of those citizens who for various reasons do not have access to the official system of vocational education, which threatens them with desocialization.

Lifelong learning makes it possible to provide conditions for meeting the individual needs of citizens in education. Examples of such needs are the need for language training, the acquisition of psy- 
chological, cultural and other knowledge, communication skills, special skills [6]. We agree with the opinion of scientists (Yu. Kovbasiuk, K. Vashchenko, Yu. Surmin) that an important area of personnel policy in the context of reproduction and effective implementation of human resources is to stimulate the development of self-education. "The need for state influence on the development of self-education is determined by social and personal necessity, the growing role of education in the life of the individual and society in modern conditions of its development" [6].

In Ukraine, the process of lifelong education administration should be improved taking into account the experience of European Union countries and, in particular, Slovakia. The creation and active development of lifelong learning centres in Slovak universities provides lifelong learning in business, management, economics, and allows participants to supplement, expand and deepen their education, retrain or prepare for a university degree. For example, Comenius University in Bratislava has a further education centre, an independent university structure that unites non-faculty departments and provides further and continuing education at this university.

In 2013 the Lifelong Learning Centre (CCV EU in Bratislava) was opened at the University of Economics in Bratislava. Its mission is to provide further education services to bachelor's, master's, engineering, and doctoral graduates, as well as to the public. CCV EU in Bratislava promotes the mission of the university in educational activities in the framework of further and continuing education following the long-term intentions of the university.

Conclusions. Thus, lifelong learning should become a scientific basis for the Ukrainian national concept of continuing education. The state must ensure effective regulation of the development of education, which promotes professional and creative self-development of the individual, preparing him for self-improvement throughout life. The trend of lifelong learning involves the formation of a new type of person who in conditions of constant socio-economic change will be able to self-realize in active work and self-development, making the maximum contribution to the transformation of the world and society, its progressive renewal. Lifelong learning is the driving force behind the formation and development of the economic, intellectual and spiritual, and cultural future of the nation. Universities can and should play an active role in implementing the strategy for providing conditions for lifelong learning. This is evidenced, in particular, by the long-term experience of lifelong learning centres established based on leading Slovak universities.

\section{СПИСОК ВИКОРИСТАНИХ ДЖЕРЕЛ ТА ЛІТЕРАТУРИ:}

1. Ажажа М.А. Державне управління модернізацією вищої освіти в Україні: монографія. Запоріжжя : Класичний приватний університет, 2019. 428 с.

2. Державна національна програма «Освіта: Україна XXI століття». Київ : Райдуга, 1994. 62 с.

3. Дубасенюк О.А. Модернізація системи освіти в Україні в умовах сучасних глобалізаційних процесів. Освітні реформи: місія, дійсність, рефлексія: монографія / за ред. В.Кременя, Т. Левовицького, В. Огневюка, С. Сисоєвої. Київ : ТОВ «Видавниче підприємство «ЕДЕЛЬВЕЙС», 2013. С. 253-262.

4. Карпенко М. Пріоритети розвитку вищої освіти в Україні у руслі загальноєвропейських тенденцій. Україна : стратегічні пріоритети. Аналітичні оцінки-2005. Київ, 2005. С. 407-416.

5. Кремень В.Г. Філософія людиноцентризму в освітньому просторі. Київ: Т-во «Знання» України, 2010.520 c.

6. Модернізація державного управління та європейська інтеграція України: наук. доп. / авт. кол.: Ю. В. Ковбасюк, К. О. Ващенко, Ю. П. Сурмін та ін. ; за заг. ред. д-ра наук з держ. упр., проф. Ю. В. Ковбасюка. Київ : НАДУ, 2013. 120 с.

7. Національна доктрина розвитку освіти. Офіційний вісник України. 03.05.2002, № 16, стор. 11, стаття 860.

8. Ничкало Н. Г. Развитие человеческого капитала - стратегическое задание профессионального образования. Модернизация профессионального образования : теория, опыт, проблемы : коллективная монография / под. ред. Т.Ю. Ломакиной. Москва : ФГНУ ИТИП РАО, 2012. 318 с.

9. Про вищу освіту: Закон від 01 липня 2014 р. № 1556-VII / Верховна Рада України. URL: https://protocol. ua/ua/pro_vishchu_osvitu_stattya_8/

10. Рекомендація щодо професійного навчання №117 (№993_106): прийняття від 27.06.1962 p. URL: https:// zakon.rada.gov.ua/laws/show/993_106

11. Степко М. Ф. Відповідність стану сучасного глобалізованого суспільства - головне стратегічне завдання розвитку системи вищої освіти. Педагогічна і психологічна науки в Україні (до 15-річчя АПН України) / ред. колегія: Сухомлинська О. В., Бех І. Д., Луговий В. І. Київ : Педагогічна думка, 2007. Т. 4. 439 с. 
12. Яковенко Л. І., Пащенко О. В. Економічні основи модернізації вищої освіти в умовах становлення економіки знань. Полтава, 2011. 216 с.

13. Gonda V., Nestorenko T. Celoživotné vzdelávanie v krajinách EÚ a krajinách mimo EÚ v kontexte agendy 2030: príklad Slovenska a Ukrajiny. Modern innovative and information technologies in the development of society. Scientific eds. A. Ostenda, T. Nestorenko, Katowice, WST, 2018. Pp. 12-26.

14. Frey C. B., Osborne M. A. The future of employment: How susceptible are jobs to computerisation? Technological Forecasting and Social Change, 2017. Vol. 114. Pp. 254-280.

15. Making a European area of lifelong learning a reality. European Commission. URL: http://viaa.gov.lv/files/ free/48/748/pol_10_com_en.pdf

16. Memorandum on Lifelong Learning. Commission of the European communities. URL: http://arhiv.acs.si/ dokumenti/Memorandum_on_Lifelong_Learning.pdf

17. Mccrone D. Cultural capital in an understated nation: the case of Scotland. Brit. J. of sociology, 2005. No 1, Vol. 56. Pp. 65-82.

18. Nestorenko T., Dubrovina N., Péliová J. Local Economic Impact of Domestic and International Students: Case of University of Economics in Bratislava. In: European Financial Systems 2016. Proceedings of the 13th International Scientific Conference, Brno: Masaryk University, 2016. Pp. 496-501.

19. Ostenda A., Nestorenko T., Ostenda J. Practical education on a higher level in Poland: example of Katowice School of Technology. Наукові записки Бердянського державного педагогічного університету. Серія : Педагогічні науки : зб. наук. пр., 2018. Вип.1. БДПУ. С. 186-190.

\section{REFERENCES:}

1. Azhazha, M.A. (2019). Derzhavne upravlinnia modernizatseiu vyshchoi osvity v Ukraini [State management of higher education modernization in Ukraine]. Monograph. Zaporizhzhia: Classical Private University.

2. Derzhavna nacional'na programa "Osvita: Ukraïna XXI stolittya" (1994). [State National Program "Education: Ukraine of the XXI Century"]. Kyiv : Raiduga, 1994. (in Ukrainian)

3. Dubaseniuk, O.A. (2013). Modernizatciia systemy osvity v Ukraini v umovach suchasnych hlobalizatsyinych protsesiv. [Modernization of the education system in Ukraine in the conditions of modern globalization processes]. Educational reforms: mission, reality, reflection. Monograph / eds. V. Kremen, T. Levovytskyi, V. Ogneviuk, S. Sysoeva. Kyiv : TOV “Vydavnyche pidpryiemstvo «EDELVEIS»”. Pp. 253-262. (in Ukrainian)

4. Karpenko, M. (2005). Priorytety rozvytku vyshchoi osvity v Ukraini u rusli zahalnoievropekskich tendentaii [Priorities for the development of higher education in Ukraine in line with European trends]. Ukraine: strategic priorities. Analytical estimates-2005. Kyiv. Pp. 407-416. (in Ukrainian)

5. Kremen, V. G. (2010). Filosofiia liudynotsentryzmu v osvitniomu prostori [Philosophy of anthropocentrism in the educational space]. Kyiv: T-vo «Znannia» Ukrainy. (in Ukrainian)

6. Modernizatsiia derzhavnoho upravlinnia ta evropeiska integratsiia Ukrainy (2013). [Modernization of public administration and European integration of Ukraine]: nauk. dop. / avt. kol. : Yu.V.Kovbasiuk, K.O. Vashchenko, Yu.P. Surmin ta in. ; za zah. red. d-ra nauk z derzh. upr., prof. Yu.V. Kovbasiuk. Kyiv : NADU. (in Ukrainian)

7. Natsionalna doktryna rozvytku osvity (2002). [National doctrine of education development]. Ofitsiinyi visnyk Ukrainy. 03.05.2002, № 16, P. 11, act 860. (in Ukrainian)

8. Nichkalo, N. G. (2012). Razvitiie chelovecheskoho kapitala - strategicheskoie zadaniie professionalnoho obrazovaniia [Human capital development is a strategic task of vocational education]. Modernization of vocational education: theory, experience, problems: collective monograph / pod. red. T.Yu. Lomakina. Moscow : FGNU ITIP RAO. (in Russian)

9. Pro vyshchu osvitu: Zakon vid 01.07.2014 (Verkhovna Rada Ukrainy). [On higher education: Law of July 1, 2014 (Verkhovna Rada Ukrainy)]. № 1556-VII, URL: https://protocol.ua/ua/pro_vishchu_osvitu_stattya_8/ (in Ukrainian)

10. Rekomendatsii shchodo profesiinogo navchannia №117 (№993_106): pryiniattia vid 27.06.1962. [Recommendation for vocational training №117 (№993_106) from 27.06.1962] URL: https://zakon.rada.gov. ua/laws/show/993_106 (in Ukrainian)

11. Stepko, M. F. (2007). Vidpovidnist' stanu suchasnogo globalizovanogo suspil'stva - golovne strategichne zavdannya rozvitku sistemi vishchoï osviti [Compliance with the state of modern globalized society is the main strategic task of the higher education system]. Pedagogical and psychological sciences in Ukraine (to the 15th anniversary of the Academy of Pedagogical Sciences of Ukraine) / red. kolehiia: Sukhomlynska O.V., Bekh I.D., Lyhovyi V.I. Kyiv : Pedahohichna dimka. Vol. 4.

12. Yakovenko, L. I., Pashchenko O. V. (2011). Ekonomichni osnovi modernizaciï vyshchoi osvity v umovah stanovlennia ekonomiki znan [Economic bases of modernization of higher education in the conditions of formation of knowledge economy]. Poltava. (in Ukrainian) 
2021 Випуск/ Issue 48

13. Gonda, V., Nestorenko T. (2018). Celoživotné vzdelávanie v krajinách EÚ a krajinách mimo EÚ v kontexte agendy 2030: príklad Slovenska a Ukrajiny. Modern innovative and information technologies in the development of society. Scientific eds. A. Ostenda, T. Nestorenko, Katowice, WST. Pp. 12-26.

14. Frey, C.B., Osborne M.A. (2017). The future of employment: How susceptible are jobs to computerisation? Technological Forecasting and Social Change. Vol. 114. Pp. 254-280.

15. Making a European area of lifelong learning a reality. European Commission. URL: http://viaa.gov.lv/files/ free/48/748/pol_10_com_en.pdf

16. Memorandum on Lifelong Learning. Commission of the European communities. URL: http://arhiv.acs.si/ dokumenti/Memorandum_on_Lifelong_Learning.pdf

17. Mccrone, D. (2005). Cultural capital in an understated nation: the case of Scotland. Brit. J. of sociology. No 1, Vol. 56. Pp. 65-82.

18. Nestorenko, T., Dubrovina N., Péliová J. (2016). Local Economic Impact of Domestic and International Students: Case of University of Economics in Bratislava. In: European Financial Systems 2016. Proceedings of the 13th International Scientific Conference, Brno: Masaryk University. Pp. 496-501.

19. Ostenda, A., Nestorenko T., Ostenda J. (2018). Practical education on a higher level in Poland: example of Katowice School of Technology. Scientific notes of Berdyansk State Pedagogical University. Series : Pedagogical Sciences : zb. nauk. pr. Vol.1. BSPU. Pp. 186-190. 